\title{
Guide Pedagogical Students to Design and Organize Experience-based Learning Activities in Schools
}

\author{
Thi Hang Nguyen \\ Thai Nguyen University of Education, Thai Nguyen City, Viet Nam \\ https://orcid.org/0000-0002-7254-968X \\ Huu Quan Nguyen \\ Thai Nguyen University of Education, Thai Nguyen City, Viet Nam \\ https://orcid.org/0000-0002-9259-746X \\ Hoang Mau Chu* \\ Thai Nguyen University of Education, Thai Nguyen City, Viet Nam \\ https:// orcid.org/0000-0002-8260-6369
}

\begin{abstract}
In Vietnam, experiential activities and experience-based learning models were first introduced in 2018 into the general education curriculum and they will be applied when implementing this program. Therefore, the teacher training program at university of education should meet the requirements of general education reform. In particular, it is essential to guide pedagogical students to design and organise experiential learning activities in the school. This study describes the design, implementation, and evaluation of a course of guiding to design and organise experience-based learning in schools for Vietnamese pedagogical students who will plan to implement experience-based learning activities into their teaching. A course in a 60-hour instructional process (including 30 hours of self-studying) with 5 activities designed to be experiential, enables our students to simultaneously explore and practice experience-based learning activities. The results of designing and organising 55 experience-based learning activity plans were obtained from one hundred and nine participants of the Faculty of Biology, Thai Nguyen University of Education, Vietnam who assessed the instructional process beneficially. The research group also proposed five effective measures to organise experiential learning in high school. This tutorial process will continue to be improved and implemented in subsequent courses to contribute to the renovation of higher education and meet the general educational improvement in Vietnam.
\end{abstract}

* Corresponding author: Hoang Mau Chu, Email: chuhoangmau@tnue.edu.vn 
Keywords: Experiential activity; Experience-based learning activities; Educational renovation; Pedagogical students; Programs of training teachers

\section{Introduction}

In pedagogical universities, the training of teacher candidates to become effective teachers is an urgent requirement. This preparation includes supporting the development of knowledge and skills for working with diverse learners (Nieto, 2013). As well as helping teacher candidates recognize how power and privilege affect educational opportunity (Gorski, 2009). It is becoming more important due to the increasing diversity of students in the university. In particular, general education in Vietnam is towards the innovation program whose objectives are to form and develop the learners' qualities and competencies. Therefore, the teacher training program in university of education is to prepare the necessary instructions for future teachers so that they be able to implement the innovative general education curriculum. Experience-based learning activities that are applied in the subjects and educational activities are in the new directions because the general education curriculum has identified experience-based learning activity as one of the compulsory education activities. Each of the experience-based learning activities is a mix of different fields of education, knowledge, and skills with a focus on practical, autonomous activities of students [Vietnam Ministry of Education and Training, 2018]. So, what and how should the teacher training program be prepared to guide pedagogical students to perform experience-based learning activities in high schools?

American Association of Colleges of Teacher Education has suggested an increased focus on clinical experiences in teacher education, including supports, and complements the innovative and requisite skills, strategies, and tools that improve teacher preparation by using high leverage practices as part of a commitment to continuous renewal for all learning sites (AACTE, 2018). Besides, providing teacher candidates educative experiences through critical servicelearning can better prepare future teachers and can foster a social justice stance (Tinkler, Tinkler, Reyes \& Elkin, 2018). These methods are based on the student's prior knowledge of experiential learning. But as for pedagogical students in Vietnam, experiential learning activity is a completely new issue. So, the way to do this is to provide experiential strategies for them in designing and organising experiential learning activities, rather than the traditional teaching models.

Experience-based learning is a process of developing knowledge, skills, and attitudes of learners by using the practical experiences (Miettinen, 2000; Cao, Tran \& Phan, 2017; Supardi \& Hasanah, 2020) and learners can reflect and analyze their progress based on their own experiences (Chapman, McPhee \& Proundman, 1984). The reflection quality of learners gained from experiencebased learning is more meaningful than the learning outcome, because "Learning is the process whereby knowledge is created through the transformation of experience" (Kolb \& Kolb, 2005). In an experience-based learning form, the learner's experience occupies a central place. The learner's 
experience may be events in a learner's life or present life, besides the skills arising during the learner participating in activities following the guidance of the teacher (Andresen, Bound \& Cohen, 1995). Experience-based learning is based on a set of hypotheses learned from experience, in which learners analyze their prior knowledge by reflecting, evaluating, and reconstructing it to receive new skills (Boud, Cohen \& Walker, 1993; McLeo, 2017; Patil \& Meena 2018). Therefore, the way which the article mentioned has focused on the process of forming and developing students' knowledge, skills, and attitudes through practical experiences in the learning process.

Theoretical and practical studies allow us to explore ways of experiential learning in guiding pedagogical students to perform experience-based learning activities in high schools. The purpose of this paper is to propose a process to guide pedagogical students to know how to design and organise experiencebased learning activities in schools that suit the renovation period of general education in Vietnam.

\section{Methods}

Pedagogical Context: The data used in this case study is generated from references vocational education related to experiential learning for students and David Kolb's four-stage experiential learning cycle. Approaching the data, the 60-hour instructional process (including 30 hours of self-studying) for pedagogical students was proposed. It can be conducted according to the operation of 5 activities that reflect four stages in Kolb's experiential learning cycle: Activity 1. Start - (1) having a real experience; Activity 2. Learning some of the theoretical issues of experience-based learning - (2) observation of and reflection on that experience; Activity 3. Building experience-based learning plan - (3) the formation of abstract concepts and generalizations; Activity 4. Practising performing experience-based learning activities, and Activity 5. Evaluation - (4) being used to test a hypothesis in future situations, resulting in new experiences.

Participants: The participants of this study are 109 pedagogical students attending the Bachelor of Pedagogy program at the Faculty of Biology, Thai Nguyen University of Education, Vietnam, the academic year of 2018-2019 and 2019-2020. The participants are allowed to attend courses to design and organise experience-based learning activities in high schools in the process of direct instruction, enhancing practice and experience which help to generate the results of designing and organisation 55 experience-based learning activities plans.

Data Collection and Analysis: The group of researchers set up assessment criteria to assess designing plans and practice of organising experience-based learning activities. Then assessment tables were provided to students to proceed with self-assessment and peer assessment. Assessment criteria relate to students' awareness of designing principles and skills and the organisation of experiencebased learning activities. Linkert scales are commonly used to measure attitude, providing a range of responses to a given question or statement (Jamieson, 2004). So, the collection and analysis of data from the survey result that using the 3-level Likert scale of students' awareness, skills, attitudes, and behaviors of the 
guiding process are effective and suitable. There are few research on instructing pedagogical students to perform experience-based learning activities in Vietnam, the research findings contribute to outline the evaluation criteria of the learning outcomes to provide information about the effectiveness of the instructional process.

The obtained research data has solved the research problem of the necessity and feasibility of guiding pedagogical students to practice designing and organising experiential learning activities. The above research data is the basis for us to propose measures to improve the implementation of experiential learning activities in high schools.

\section{Results and discussion}

\subsection{The process of instruct students to perform experiential learning activities} in the schools

The principles and practices of experiential learning have been widely adopted in models, programs to conduct academic courses such as competency-based education (Miettinen, 2000; Ahmed, 2018), professional training (Richard, Cowen \& Kolb, 1995; Akhigbe, 2018; Amolloh, Lilian \& Wanjiru, 2018; Tiessen, Grantham \& Cameron, 2018; Stefano, Ruvolo \& Mauro, 2019), college programs for adult learners, and prior learning assessment (Simosko, 1998; Andrews, Brown \& Mesher, 2018; Awidi \& Paynter, 2019; Bhati \& Song, 2019), service learning (Angela, Bruce, Kevin, Mandar \& Kurtis, 2011; Aissaoui, Alami, Oughdir \& Allioui, 2018), problem-based learning (Bethell \& Morgan, 2011; Gomez \& Nasir, 2019; Harfitt, 2019; Stephanie, Lockwood, Hill \& Randell, 2020; Setiyani, Harnanik, Lianighsih \& Susilowati, 2020), action learning (Louise, 1994). The experiential lessons provide students with an opportunity to experience concepts, give students a more productive, more meaningful understanding of course concepts, and of how they operate in the real world. So, the affective quality of the course content is enhanced. A wide range of forms of experience-based learning has been used in vocational and professional education such as internships, work-placements, on-the-job training, excursions, adventure, wilderness trips, studios, laboratories, workshops, clinical, practicums, case study approaches, action research, role-plays, hypotheticals, and simulations, active learning in lectures, computer simulations, realistic models, video-based activities, group discussions and syndicate methods, autobiographical writing, problem-based learning, group work, reflective journals and self-directed projects.

David Kolb's experiential learning theory, which is developed from Kolb and Kolb's research, works on two levels: a four-stage cycle of learning and four separate learning styles) (McLeo, 2017) studying experiential learning and exploring how this work can enhance experiential learning in higher education. Kolb and Kolb (2005) introduced the concept of learning space as a framework for understanding the interface between the student's learning style and institutional learning environment, showing the principles for enhancing of experiential learning in higher education and suggested how experiential learning should be applied throughout the educational environment by 
institutional development programs. Kolb's experiential learning cycle (Fig. 1) divides the learning process into a period of four essential theoretical components. Therefore, the development of new concepts provided by new experiences will be emerged. "Knowledge is continuously derived from and tested out in the experiences of the learner". The process of learning from experience is ubiquitous, present in human activity everywhere all the time. The holistic nature of the learning process means that it operates at all levels of human society from the individual to the group, organisation, and society (Andresen, Bound \& Cohen, 1995; Kolb and Kolb, 2017) were applying experiential learning in the accordant educational environment and learning styles to develop curriculum, students and faculty.

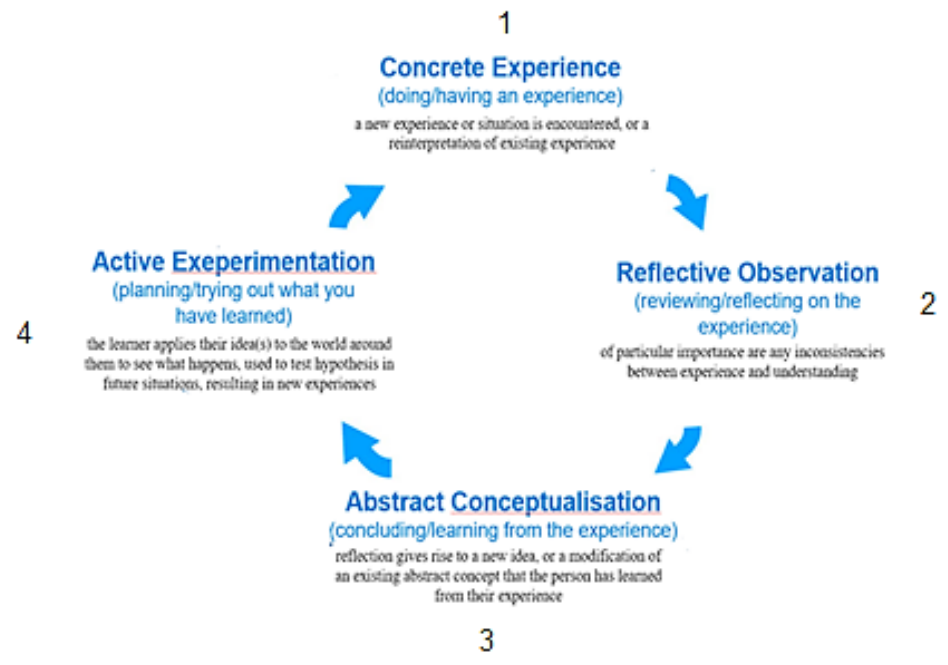

Figure 1: Diagram of Kolb's Experiential Learning Cycle (McLeo, 2017).

1. Concrete Experience - a new experience or situation is encountered, or a reinterpretation of existing knowledge. 2. Reflective Observation of the New Experience - of particular importance are any inconsistencies between knowledge and understanding. 3. Abstract conceptualization reflection gives rise to a new idea, or a modification of an existing abstract concept (the person has learned from their experience). 4. Active experimentation - the learner applies their concept to the world around them to see what happens.

Kolb's experiential learning cycle includes concrete experience, reflective observation, abstract conceptualization, and active experimentation was used to create the innovative framework integrated between experiential learning with project planning in civil engineering and construction management courses (Zhang, Xie, Schmidt, Xia, Li \& Skitmore, 2019). It was also used to research experiential learning in engineering education by comparing the practising of Spoken Tutorial with placement activity of students and lastly, identifying the environmental and structural effects of the experiential learning process (Patil \& Meena, 2018). Kolb Learning Cycle was employed as the fundamental pedagogic of the 'Heat Transfer' course in mechanical engineering education, to facilitate students' understanding of tricky mathematical concepts (Widiastuti \& Budiyanto, 2018). A model for laboratory education based on Kolb's experiential learning theory is used in modern teaching technologies and a combination of remote, virtual, and hands-on laboratory sessions to apply in the teaching of the undergraduate process control laboratory (Abdulwahed \& Nagy, 2013). Kolb's 
Learning Cycle theory is the overarching theory of learning, include a range of teaching methods that are useful for quantitative reasoning (Wallace, 2018).

Studies of experiential learning show that learners' experience-based learning activities occupy a central place in the experience-based learning process. The application of Kolb's experiential learning cycle, when instructing students to organise experience-based learning in schools can be conducted according to the operation of activities.

Activity 1. Start

Activity 2. Learn some of the theoretical issues of experience-based learning

Activity 3. Practice building an experience-based learning plan

Activity 4. Practice performing experience-based learning activities

Activity 5. Evaluation

The above procedure reflects four stages in Kolb's experiential learning cycle: (1) having a real experience (activity 1$) \rightarrow(2)$ observation of and reflection on that experience (activity 2) $\rightarrow$ (3) the formation of abstract concepts and generalization (activity 3) $\rightarrow$ (4) used to test a hypothesis in future situations, resulting in new experiences (activity 4,5 ).

The following are detailed guidelines for implementing the above process (Table 1).

Table 1: The process of guiding students to organise experience-based learning activities

\begin{tabular}{|c|c|c|c|c|}
\hline Activity & Objectives & Preparation & Process & Assessment \\
\hline $\begin{array}{l}\text { Activity 1: } \\
\text { Start }\end{array}$ & $\begin{array}{l}\text { 1) Acquaint } \\
\text { with class } \\
\text { members; } \\
\text { 2) Share } \\
\text { personal } \\
\text { information } \\
\text { with other } \\
\text { members; } \\
\text { 3) Proposing } \\
\text { and agreeing } \\
\text { with the } \\
\text { rules and } \\
\text { objectives of } \\
\text { the course. }\end{array}$ & $\begin{array}{l}\text { Duration: } 2 \\
\text { hours; } \\
\text { Location: } \\
\text { Lecture hall; } \\
\text { Learning } \\
\text { materials: A4 } \\
\text { paper, } \\
\text { coloured } \\
\text { paper, } \\
\text { diagram of } \\
\text { seat position. }\end{array}$ & $\begin{array}{l}\text { 1) Students are provided } \\
\text { color paper and A4 paper. } \\
\text { They are required to write } \\
\text { their names in capital letters } \\
\text { on coloured paper, proposed } \\
\text { rules of the class and } \\
\text { expectations of the course on } \\
\text { the A4 paper (short written, } \\
\text { limited to } 10 \text { words), and } \\
\text { then put in front of them. } \\
\text { 2) Two students who sit next } \\
\text { to each other exchange their } \\
\text { personal information. } \\
\text { 3) Introduce their partners } \\
\text { with known personal } \\
\text { information after discussion. } \\
\text { 4) Request the students to } \\
\text { cover the name, give them a } \\
\text { location map, and then ask } \\
\text { the students to fill in the } \\
\text { name of their classmate with } \\
\text { encouragement to write the } \\
\text { most accurate name. } \\
\text { 5) Unify objectives and rules } \\
\text { to be implemented by voting } \\
\text { proposals of students. } \\
\text { Note: The instructor plays a } \\
\text { moderated role to give }\end{array}$ & $\begin{array}{l}\text { Ask the } \\
\text { participants } \\
\text { about the } \\
\text { meaning of } \\
\text { the course } \\
\text { rules and } \\
\text { how to set up } \\
\text { the rules. }\end{array}$ \\
\hline
\end{tabular}




\begin{tabular}{|c|c|c|c|c|}
\hline & & & $\begin{array}{l}\text { important information as } \\
\text { well as a member of the } \\
\text { class. }\end{array}$ & \\
\hline $\begin{array}{l}\text { Active 2: } \\
\text { Learn } \\
\text { some of } \\
\text { the } \\
\text { theoretical } \\
\text { issues of } \\
\text { experienc } \\
\text { e-based } \\
\text { learning }\end{array}$ & \multirow{3}{*}{$\begin{array}{l}\text { 1) Analyse } \\
\text { the concepts, } \\
\text { characteristic } \\
\text { s of } \\
\text { experience- } \\
\text { based } \\
\text { learning; } \\
\text { 2) Identify } \\
\text { criteria, } \\
\text { methods, } \\
\text { and tools for } \\
\text { evaluating } \\
\text { experience- } \\
\text { based } \\
\text { knowledge } \\
\text { in schools; } \\
\text { 3) Determine } \\
\text { the content } \\
\text { and the form } \\
\text { of } \\
\text { experience- } \\
\text { based } \\
\text { learning } \\
\text { activities in } \\
\text { schools; } \\
\text { 4) Explain } \\
\text { the } \\
\text { organisation } \\
\text { of each type } \\
\text { of } \\
\text { experience- } \\
\text { based } \\
\text { learning } \\
\text { activities in } \\
\text { schools; } \\
\text { 5) Construct } \\
\text { a plan to } \\
\text { organise } \\
\text { experience- } \\
\text { based } \\
\text { learning } \\
\text { activities in } \\
\text { schools; } \\
\text { 6) Practice } \\
\text { organising a } \\
\text { specific } \\
\text { experience- } \\
\text { based } \\
\text { learning } \\
\text { activity in }\end{array}$} & \multirow{3}{*}{$\begin{array}{l}\text { Duration: } 54 \\
\text { hours, } \\
\text { including } 30 \\
\text { hours of self- } \\
\text { study; } \\
\text { Location: } \\
\text { Lecture hall } \\
\text { and some } \\
\text { places where } \\
\text { to organise } \\
\text { experience- } \\
\text { based } \\
\text { learning } \\
\text { activities. } \\
\text { The choice of } \\
\text { venue } \\
\text { depends on } \\
\text { the designed } \\
\text { plan; } \\
\text { Learning } \\
\text { materials: A0 } \\
\text { paper, A4 } \\
\text { paper, } \\
\text { markers; } \\
\text { Index cards; } \\
\text { Leaflet of } \\
\text { experience- } \\
\text { based } \\
\text { learning } \\
\text { activities; } \\
\text { Computer } \\
\text { with an } \\
\text { internet } \\
\text { connection, } \\
\text { projector. }\end{array}$} & $\begin{array}{l}\text { 1) The class is divided into } \\
\text { small groups to do specific } \\
\text { tasks; } \\
\text { 2) The groups search for } \\
\text { information, discuss the } \\
\text { content in index cards and } \\
\text { write their discussion results } \\
\text { in the A0 paper; } \\
\text { 3) Instructors direct the } \\
\text { groups to read the relevant } \\
\text { information carefully in the } \\
\text { brochure; } \\
\text { 4) Groups present their } \\
\text { results with A0 paper in } \\
\text { turn. The other groups } \\
\text { raised the question; } \\
\text { 5) The class is in agreement } \\
\text { with the content. }\end{array}$ & $\begin{array}{l}\text { Consider the } \\
\text { adequacy of } \\
\text { information } \\
\text { about the } \\
\text { content of } \\
\text { each group } \\
\text { on A } \text { A paper, }_{\text {product }} \\
\text { presentation, } \\
\text { teamwork } \\
\text { attitude. }\end{array}$ \\
\hline $\begin{array}{l}\text { Active 3: } \\
\text { Practice } \\
\text { for } \\
\text { designing } \\
\text { plan EBL } \\
\text { activities }\end{array}$ & & & $\begin{array}{l}\text { 1) The class is divided into } \\
\text { small groups to make an } \\
\text { EBL plan; } \\
\text { 2) The groups discuss and } \\
\text { write their idea on A4 and } \\
\text { A0 paper. The groups also } \\
\text { compose the presentation on } \\
\text { the computer; } \\
\text { 3) Groups present their } \\
\text { products with their posters } \\
\text { and the display on the } \\
\text { computer in turn. The other } \\
\text { groups raise the question } \\
\text { and make some comments; } \\
\text { 4) The group is in agreement } \\
\text { with their EBL plan. }\end{array}$ & $\begin{array}{l}\text { Consider the } \\
\text { adequacy of } \\
\text { information } \\
\text { about the } \\
\text { content of } \\
\text { each group's } \\
\text { plan, how to } \\
\text { present their } \\
\text { idea. }\end{array}$ \\
\hline $\begin{array}{l}\text { Active 4: } \\
\text { Practice } \\
\text { for } \\
\text { organising } \\
\text { experienc } \\
\text { e-based } \\
\text { learning } \\
\text { activities }\end{array}$ & & & $\begin{array}{l}\text { 1) A representative of the } \\
\text { group introduces how to } \\
\text { conduct the experience- } \\
\text { based learning activities that } \\
\text { the group has planned since } \\
\text { Activity 3; } \\
\text { 2) Other students play the } \\
\text { role of participants in the } \\
\text { experience-based learning } \\
\text { activities; } \\
\text { 3) The students make } \\
\text { comments on the } \\
\text { organisation of the } \\
\text { experience-based learning } \\
\text { activities. Thus, each group } \\
\text { gains valuable experience in }\end{array}$ & $\begin{array}{l}\text { Based on the } \\
\text { plan of } \\
\text { organising } \\
\text { experience- } \\
\text { based } \\
\text { learning } \\
\text { activities that } \\
\text { the groups } \\
\text { build, } \\
\text { consider the } \\
\text { feasibility } \\
\text { and } \\
\text { effectiveness } \\
\text { of the } \\
\text { organisationa } \\
\text { l project. }\end{array}$ \\
\hline
\end{tabular}




\begin{tabular}{|c|c|c|c|c|}
\hline & schools. & & $\begin{array}{l}\text { the organisation. Besides, } \\
\text { they can improve their plan } \\
\text { as well as the feasibility of } \\
\text { the project. }\end{array}$ & \\
\hline $\begin{array}{l}\text { Active 5: } \\
\text { Evaluatio } \\
\mathrm{n}\end{array}$ & $\begin{array}{l}\text { 1) } \\
\text { Systematise } \\
\text { the main } \\
\text { activities of } \\
\text { the course. } \\
\text { 2) Do self- } \\
\text { assessment } \\
\text { of self- } \\
\text { achievement } \\
\text { compared to } \\
\text { course goals. } \\
\text { 3) Apply } \\
\text { planning and } \\
\text { organising } \\
\text { experience- } \\
\text { based } \\
\text { learning } \\
\text { activities to } \\
\text { their } \\
\text { teaching } \\
\text { plans. }\end{array}$ & $\begin{array}{l}\text { Duration: } 2 \\
\text { hours; } \\
\text { Location: } \\
\text { Lecture hall; } \\
\text { Learning } \\
\text { materials: } \\
\text { Index cards; } \\
\text { A specific } \\
\text { plan for the } \\
\text { application } \\
\text { of } \\
\text { experience- } \\
\text { based } \\
\text { learning } \\
\text { organisation } \\
\text { in schools. }\end{array}$ & $\begin{array}{l}\text { 1) The instructor distributes } \\
\text { the index card to students } \\
\text { and requests them to } \\
\text { complete the index card; } \\
\text { 2) The instructor summarises } \\
\text { the main activities of the } \\
\text { course; } \\
\text { 3) Instructor agrees with the } \\
\text { student about the next } \\
\text { specific application plan; } \\
\text { 4) Students discuss the } \\
\text { advantages, disadvantages, } \\
\text { and remedies for practising } \\
\text { planning and organising } \\
\text { experience-based learning } \\
\text { activities in high school; } \\
\text { 5) Students comment and } \\
\text { draw experience for the } \\
\text { content, organisation of the } \\
\text { course. }\end{array}$ & $\begin{array}{l}\text { Students' } \\
\text { knowledge, } \\
\text { skills and } \\
\text { attitudes } \\
\text { about } \\
\text { experience- } \\
\text { based } \\
\text { learning } \\
\text { activities in } \\
\text { schools, and } \\
\text { the progress } \\
\text { of themselves } \\
\text { for this } \\
\text { activity. }\end{array}$ \\
\hline
\end{tabular}

The instructional process was conducted on a schedule of direct instruction, with clear objectives focusing on two outcomes: (i) designing of the experiencebased learning activity plans that are ulterlized as direction to develop students' competencies, and (ii) organising experience-based learning activities that are recorded to be able to review, analyse, evaluate, and respond. During the instructional process, the researchers encouraged students to give feedback on their understanding of the content and their experience in activities, so that appropriate modifications could be made.

3.2. Results of designing and organisation of experience-based learning activities The above experience-based learning guideline process was conducted in the second semester of the school year 2018-2019 and the first semester of the school year 2019-2020 in the Faculty of Biology, Thai Nguyen University of Education, Vietnam with 109 students participating. The results are reflected in the designed plans for experience-based learning in schools and the organisation of these plans.

\subsubsection{The results of the designing of experience-based learning activities plans} When students design experience-based learning activities plans, they should identify the essential components. These are realistic goals; exciting topics or learning contexts; learners' needs and talents; teaching approaches and methods; appealing resources and experiences that are relevant and linked to the learners' lives and context; fair assessment and evaluation (Kumar \& Kumari, 2019). 
Designing the plans to organise experience-based learning activities are conducted according to flexible principles and processes and are described by the following structure:

\section{Reasons}

The name of the experience-based learning activity

II. Objectives

III. Preparations

$1 /$ Contents of experience-based learning activities

2/ Methods and organisation form

3/ Facilities and learning materials

4/ Assignments

IV. Progress

1/ Stage 1 (before the lesson): Students have introduced the activity plan, content preparation, and facilities necessary for the activity, and the product of the activity.

2/ Stage 2 (during the lesson): Warm-up activities:

a/ Starting activities: Role-plays, games, etc.

b/ Main activities: Activity 1, Activity 2, etc. Each activity introduces the objectives, facilities, measures, forms, performers, activities, and products.

c/ Ending activities: Discussion, completion, and summarization

3/ Stage 3 (after the lesson): Students were required to complete their products, write a report, self-study, and prepare for other activities.

V. Evaluation of activities: Students were assessed on the capacity to perform activities, drawing experience for the activities.

Based on detailed instructions, students have designed 55 experience-based learning activities plans. The plans have shown the richness and diversity of topics (Table 2), contents, forms of organisation, presentation style; and ensure the science, feasibility, and effectiveness.

Table 2: Experience-based learning themes in the designed plans

\begin{tabular}{|l|l|l|}
\hline \multicolumn{2}{|c|}{$\begin{array}{c}\text { Form of Experience-based } \\
\text { learning activities }\end{array}$} & \multicolumn{1}{c|}{ Themes } \\
\hline $\begin{array}{l}\text { The } \\
\text { discovery } \\
\text { form }\end{array}$ & $\begin{array}{l}\text { - Fieldwork, } \\
\text { practical } \\
\text { - Sightseeing } \\
\text { - Camp } \\
\text { - Game }\end{array}$ & $\begin{array}{l}\text { - Sightseeing: + Vegetable field ...; + Clean } \\
\text { vegetable garden at...; + Tea Village ...; + Mushroom } \\
\text { growing facility...; + See circus animals; } \\
\text { - Discover: + Primary forest in forest ... + } \\
\text { Traditional village; + Make friends with farmers: } \\
\text { Plant protection chemicals - Friends or Hostility; + } \\
\text { Surveying the environment in trade villages ...; + } \\
\text { Green lungs of the earth; + Fair for recycled } \\
\text { products }\end{array}$ \\
\hline $\begin{array}{l}\text { The } \\
\text { scientific } \\
\text { research, } \\
\text { division } \\
\text { form }\end{array}$ & - Project and & $\begin{array}{l}\text { - Produce sprouts from seeds; Growing hydroponic } \\
\text { vegetables; } \\
\text { - Water and daily life; }\end{array}$ \\
& & $\begin{array}{l}\text { - Plant cell and tissue culture; } \\
\text { - Protect plants properly and safely; } \\
\text { - "Biological" vegetable, Organic vegetable; } \\
\text { - Microbiological technology in the treatment of } \\
\text { environmental pollution; }\end{array}$ \\
\hline
\end{tabular}




\begin{tabular}{|c|c|c|}
\hline & - Clubs & $\begin{array}{l}\text { - Shark tank for the student; } \\
\text { - Green Environment Club: + Climate change; + } \\
\text { Domestic Waste + Join our hands together to make } \\
\text { our environment clean, green, and beautiful } \\
\text { environment; } \\
\text { - Sex Education Club: + I have grown up; + } \\
\text { Adolescent reproductive health; } \\
\text { - Biological Club for Life: + Biological colors; + } \\
\text { Young biological manufacturing; + Microorganisms } \\
\text { and life; } \\
\text { - Career Club: + I am in the future; + Microbiologist } \\
\text { + Microbiological kitchen. }\end{array}$ \\
\hline $\begin{array}{l}\text { The } \\
\text { experiment } \\
\text { al, } \\
\text { interactive } \\
\text { form }\end{array}$ & $\begin{array}{l}\text { - Forum } \\
\text { - Exchange } \\
\text { - Workshop / } \\
\text { Seminar } \\
\text { - Chemical } \\
\text { stage } \\
\text { - Competition }\end{array}$ & $\begin{array}{l}\text { - Earth's future; } \\
\text { - Vietnamese - Lao cuisine; } \\
\text { - Care and protect adolescent health; } \\
\text { - Care and protect reproductive health in schools; } \\
\text { - Health is a diamond; } \\
\text { - Food hygiene and safety; } \\
\text { - The microbiological arena; } \\
\text { - HIV/ AIDS and the community; } \\
\text { - Join hands to fight HIV/ AIDS; } \\
\text { - Garbage: Angel or Devil? } \\
\text { - Production of biological insecticides; } \\
\text { - Designing biological experiment models; } \\
\text { - Designing models of Biological teaching }\end{array}$ \\
\hline $\begin{array}{l}\text { Dedication } \\
\text { form }\end{array}$ & $\begin{array}{l}\text { - Practice } \\
\text { housework, } \\
\text { school work } \\
\text { - Social/ } \\
\text { volunteer } \\
\text { activities }\end{array}$ & $\begin{array}{l}\text { - Growing clean vegetables. } \\
\text { - Making black garlic. } \\
\text { - Planting, tending, and harvesting local specialty } \\
\text { trees ... } \\
\text { - Making friends with the Tan Cuong tree (Dai Tu, } \\
\text { Thai Nguyen). } \\
\text { - A day as a farmer. } \\
\text { - Campaign for waste collection and treatment. } \\
\text { - Environmental sanitation campaign and new rural } \\
\text { construction. } \\
\text { - Propaganda and prevention of HIV/ AIDS. } \\
\text { - Propagate, care for, and protect the reproductive } \\
\text { health of adolescents. } \\
\text { - Propagating and preventing infectious diseases. } \\
\text { - The war: "Stealing rubbish" - Organic waste. }\end{array}$ \\
\hline
\end{tabular}

Among the topics of experiential learning activities that have been designed, we are very interested in STEM (Science - Technology - Engineering - Mathematics) education-oriented activities, such as the Production of biological insecticides; Designing an experiment of biological models; Making Bio-Products for environmental protection, etc. The design and organisation of STEM experiencebased learning activities is a direction that needs to be studied deeply and fully (Razali, Manaf \& Ayub, 2020). In the next studies, we will introduce STEM experience-based learning activities.

\subsubsection{The results of the students' organising experience-based learning activities}


After the plans of the experience-based learning activities are approved, students practice for organising experience-based learning activities in the lecture hall, at schools, and venues. Students were trained as cameramen, photographers for recording the process of experience-based learning activities.

The students applied the process to organise experience-based learning activities. The process includes three stages, each stage is concretized by steps or tasks:

Stage 1. Before the activity, including three steps:

- Step 1. Plan to organise experience-based learning activities

- Step 2. Disseminate the plan

- Step 3. Prepare for the plan

Stage 2. During the activity, including three steps:

- Step 1. Check the preparations

- Step 2. Conduct experience-based learning activities

- Step 3. Evaluate the experience-based learning activities

Stage 3. After the activity, including the works:

- Write the report

- Answer questions, do homework

- Self-learning

The following pictures show the organising experience-based learning activities of students (Fig. 2).

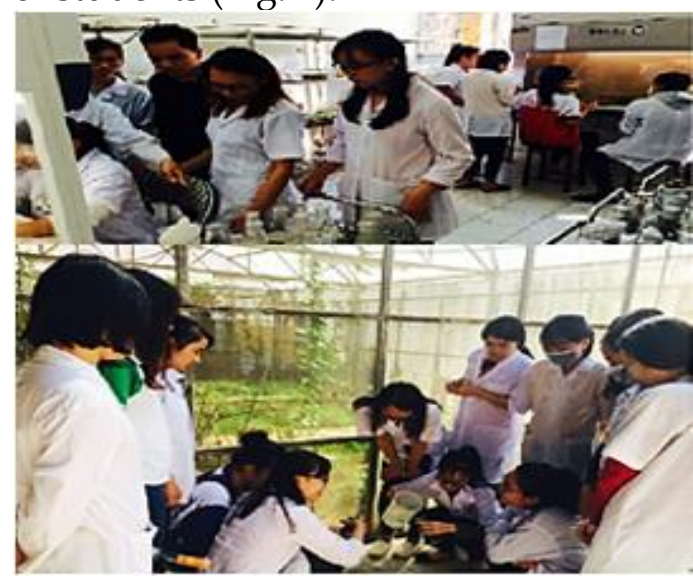

Pedagogical students practice organising activity Plant cell and tissue culture -

Experimental activity of scientific research

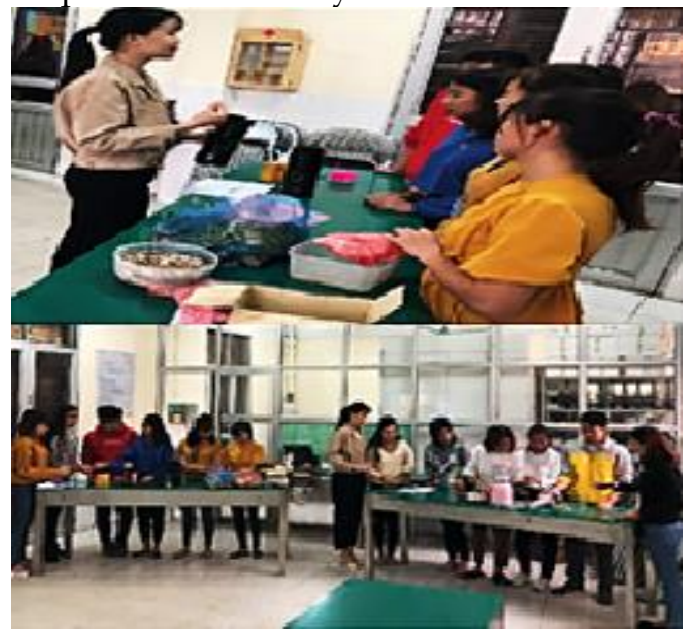

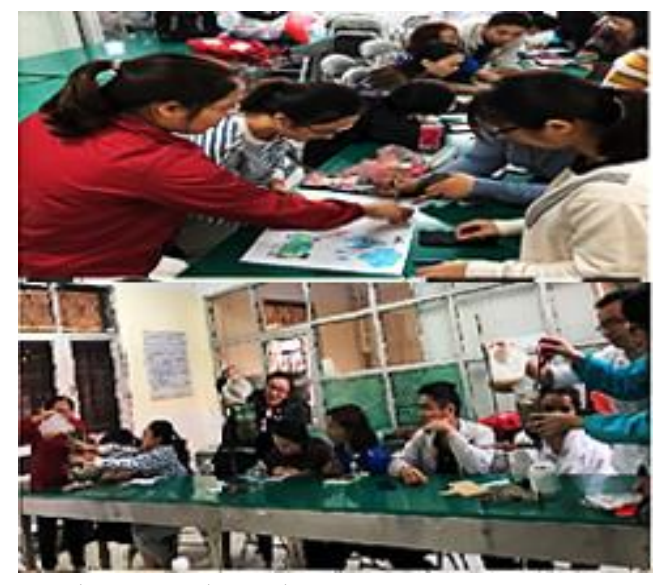

Pedagogical students practice organising activity To make water purification equipment - Project activity.

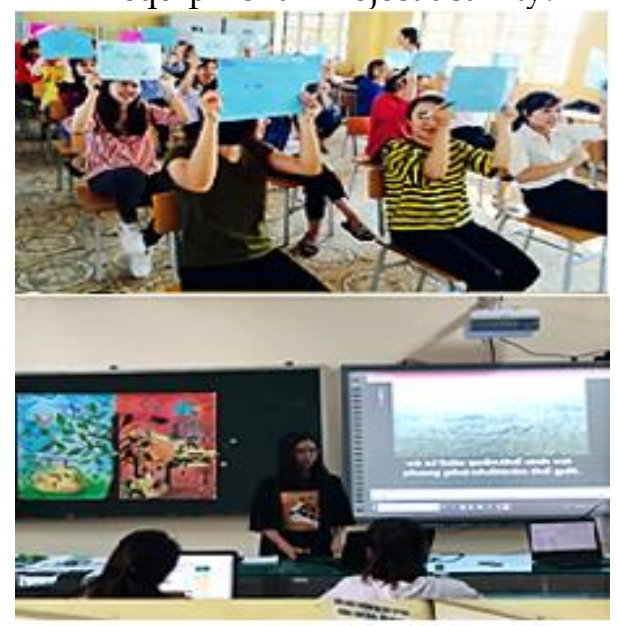


Students practice organising activity the manufacture of insect and pest preventing products - STEM experience activity

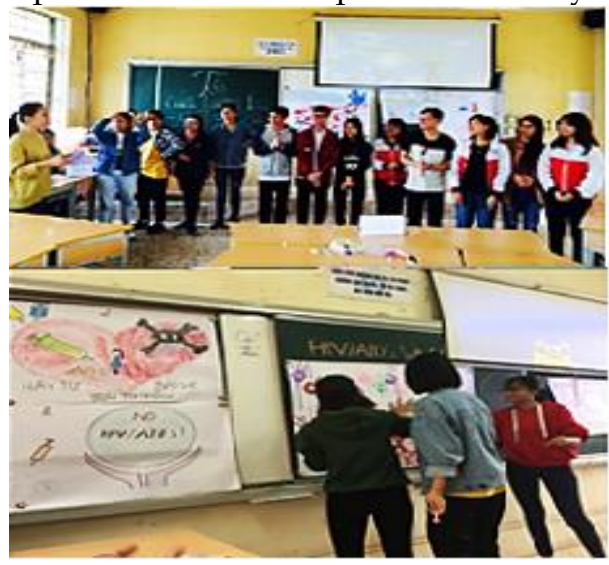

Students practice organising activity Propaganda and prevention of HIV/AIDS Social/volunteer activity
Pedagogical students practice organising Green Environment Club - Seminar

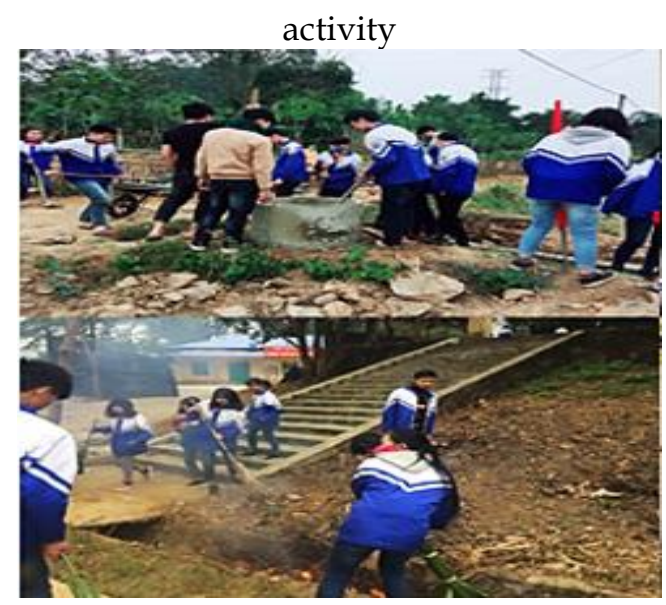

Students participate in activity The campaign for environmental protection organised by pedagogical students

Figure 2: Photos of the students doing the experience-based learning activities

When being encouraged to give feedback on their understanding of the content and experience in activities, generally, the participants gave very favorable reviews to the instructional process. They said that process helped them to have an understanding of knowledge and skills to practice designing and organising experience-based learning activities, which is very useful for their teaching in the future. For example, one participant highlighted her initial reluctance to the approach. However, after participating in discussing and implementing the assigned tasks, she recognised the benefits of the instructional process:

I have learned a lot and been able to apply it to my teaching. At first, I didn't think it would suit me but the course turned out to be very effective and helpful. Some other students also had similar comments and intended to integrate experiential learning and aspects of the course into an apprenticeship and apply it in their lessons. Some participants wished to have more material and time to complete activities and more activities organised directly in schools rather than practice at the pedagogical university. The researcher is going to review this idea and add it to the guiding process.

Survey on awareness, skills, attitudes, and behaviours of students by Likert 3level scale questionnaire (about knowledge of the plans' contents: Suitable, Not appropriate, Not Suitable; about design and organise experience-based learning activities skills: Proficient, Not proficient, Not proficient; about attitude: Agree, Unsure, Disagree; and about behaviour: Often, Sometimes, Never) with related contents and activities, showing the degree of differentiation of students in the course (Fig. 3, Fig.4, and Table 3). 


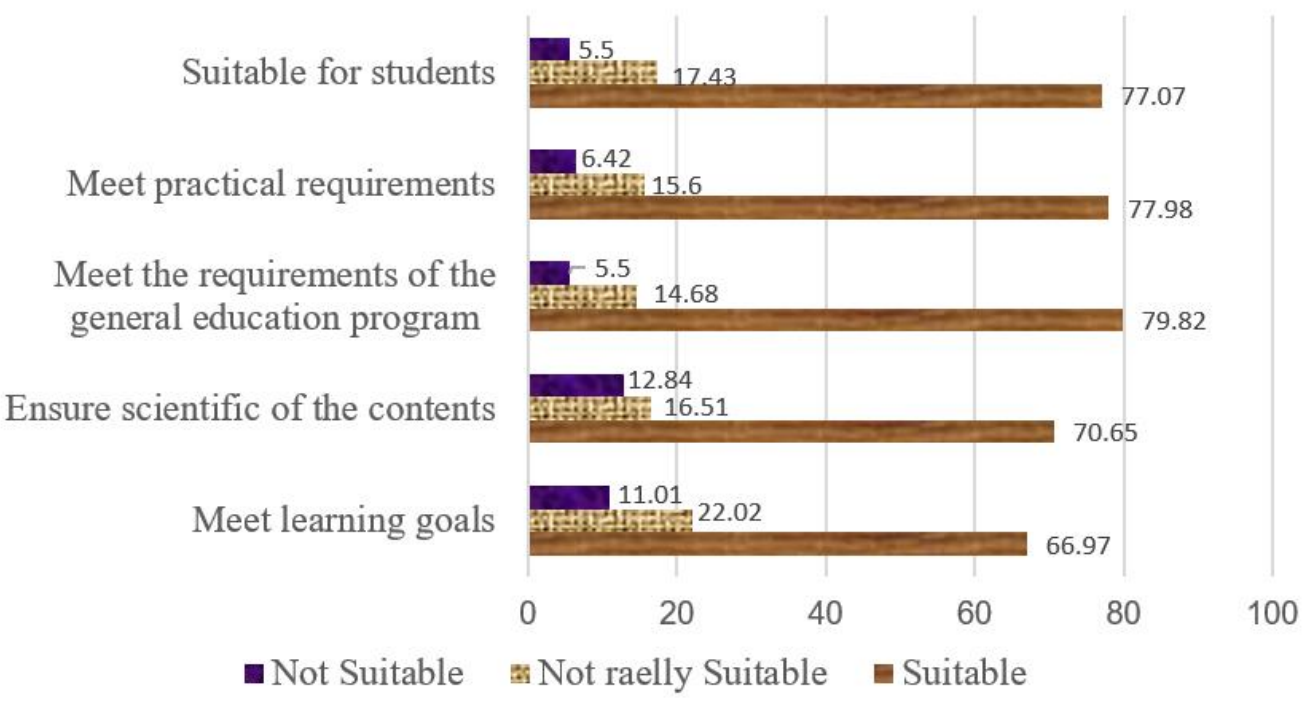

Figure 3: The analytical chart of the awareness of students for design principles of experience-based learning activity plans

The analytical results in Figure 3 have shown that most students when designing experience-based learning activities plans are interested in the principles: Meet teaching goals $(66.97 \%)$, ensure scientific of the contents $(70.65 \%)$, meet the requirements of the general education program $(79.82 \%)$, meet practical requirements $(77.98 \%)$ and suitable for students $(77.07 \%)$. However, some students $(5.5 \%-12.84 \%)$ are not fully aware of these principles. These students were incorporated into more aware student groups.

Complete the active organization plan

Implementation of specific activities

Identify and use the conditions.

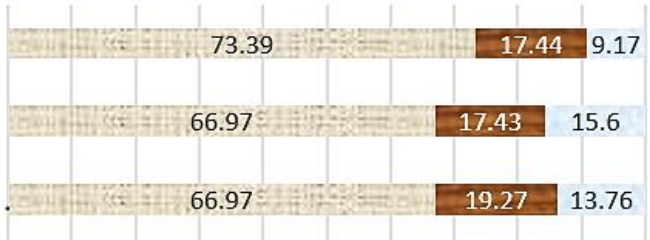

Select the form of active organization

Determine the active content

Writing active objectives enough 3 fields

Name the activity

Identify organizational needs

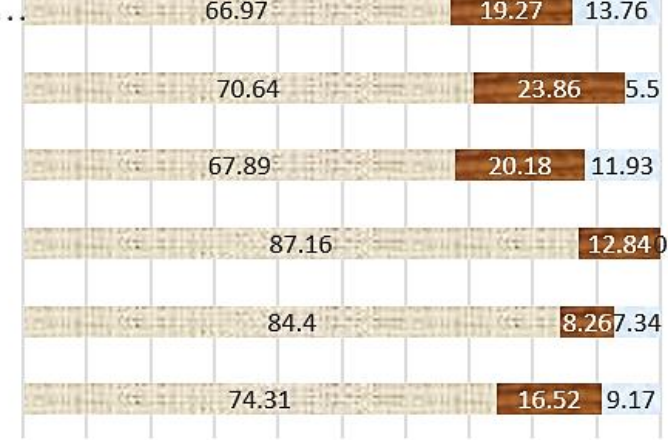

$\begin{array}{llllllllllll}0 \% & 10 \% & 20 \% & 30 \% & 40 \% & 50 \% & 60 \% & 70 \% & 80 \% & 90 \% & 100 \%\end{array}$

$$
\square \text { Proficient } \quad \text { Not really proficient Not proficient }
$$

Figure 4: The analytical chart of the proficient student rate in designing and organising experience-based learning activities

The analytical chart in Figure 4 showed that the skills that students have mastered as writing activity objectives enough three fields (knowledge, skills, 
attitude: $87.16 \%)$, name the activity $(84.4 \%)$, other skills as identify organisational needs, select the form of activity organisation, complete the activity organisation plan, identify and use the conditions necessary to organise the activities, determine the activity content, plan of specific activity, students were practiced quite competently. Besides, there are many students (nearly 30\%) who are not proficient and not proficient in designing and organising experience-based learning activity skills. These students need to practice more by referring to the skills of other students.

Table 3: Students' attitudes and behaviour towards experience-based learning activity design and organisation course

\begin{tabular}{|l|c|c|c|c|c|c|}
\hline \multicolumn{1}{|c|}{ Activities } & \multicolumn{3}{|c|}{ Attitude (\%) } & \multicolumn{3}{c|}{ Behaviour (\%) } \\
\cline { 2 - 7 } & Agree & Unsure & Disagree & Often & $\begin{array}{c}\text { Sometime } \\
\text { s }\end{array}$ & Never \\
\hline $\begin{array}{l}\text { 1. Familiarise and } \\
\text { share personal } \\
\text { information }\end{array}$ & 100.00 & 0.00 & 0.00 & 82.57 & 13.76 & 3.67 \\
\hline $\begin{array}{l}\text { 2. Building and } \\
\text { unifying the course } \\
\text { rules and objectives }\end{array}$ & 87.16 & 12.84 & 0.00 & 82.57 & 17.43 & 0.00 \\
\hline $\begin{array}{l}\text { 3. Learn the } \\
\text { theoretical issues of } \\
\text { experiential learning }\end{array}$ & 84.40 & 14.68 & 0.92 & 72.48 & 26.61 & 0.92 \\
\hline $\begin{array}{l}\text { 4. Explain the } \\
\text { content and } \\
\text { organisation of } \\
\text { experiential learning } \\
\text { activities }\end{array}$ & 74.31 & 13.76 & 11.93 & 64.22 & 18.35 & 17.43 \\
\hline $\begin{array}{l}\text { 5. Develop a plan for } \\
\text { organising } \\
\text { experiential learning } \\
\text { activities }\end{array}$ & 81.65 & 16.51 & 1.83 & 64.22 & 30.28 & 5.50 \\
\hline $\begin{array}{l}\text { 6. Actively } \\
\text { participate in the } \\
\text { organisation of } \\
\text { experiential learning } \\
\text { activities }\end{array}$ & 85.32 & 14.68 & 0.00 & 76.15 & 15.60 & 8.26 \\
\hline $\begin{array}{l}\text { 7. Identify } \\
\text { advantages and } \\
\text { disadvantages when } \\
\text { organising } \\
\text { experiential learning } \\
\text { activities }\end{array}$ & 77.98 & 18.35 & 3.67 & 68.81 & 28.44 & 2.75 \\
\hline $\begin{array}{l}\text { 8. Self-improvement } \\
\text { of the plan of } \\
\text { organising } \\
\text { experiential learning } \\
\text { activities }\end{array}$ & 73.39 & 17.43 & 9.17 & 64.22 & 22.02 & 13.76 \\
\hline
\end{tabular}

Table 3 shows the differentiation of students' attitudes and behaviours towards the activities in the course. The majority of students agreed with the course's 
activities: Familiarise and share personal information (100\%), Building and unifying the course rules and objectives $(87.16 \%)$, Actively participate in the organisation of experiential learning activities (85.32\%), Learn the theoretical issues of experiential learning $(84.4 \%)$, Develop a plan for organising experiential learning activities (81.65\%), Explain the content and organisation of experiential learning activities (74.31\%), Identify advantages and disadvantages when organising experiential learning activities (77.98\%), Self-improvement of the plan of organising experiential learning activities (73.39\%); Low percentage of students disagree with these activities (nearly $10 \%$ ).

The student's consent is expressed through the habit of regularly participating in activities that account for a high proportion (over $64 \%$ ). However, some students are uncertain about the activities (12-19\%) and only occasionally active (13-31\%). Some students do not participate and do not agree with some activities (less than $12 \%$ and less than 18\%) should be considered causes, can look at the attractiveness of these activities.

The above survey results show the necessity and feasibility of activities in the process of guiding students to design and organise experience-based learning activities in schools. However, the difference in survey outcomes among course participants shows that some students were not interested in the course activities. By observing the course activities, some students were reluctant to participate in group activities or did their jobs. When being asked about the reason for that, they replied that they often had to work part-time or be influenced by other jobs, so they did not have time for self-study exercises, did not have enough knowledge and skills to perform activities which leads to an idea for our further studies on the distribution of group participants and having plans to design online courses or the course that combination of face-to-face and online learning for participants groups.

\subsection{Suggested measures to improve the performance of experience-based learning activities in the schools}

Based on the results of the process of the guide to the organisation of experiencebased learning activities, researchers have proposed some measures below in order to implement experience-based learning activities effectively.

1) Encourage and respect students' choices on the form and the content of experience-based learning the instructor gives specific guidance and suggestions to students from planning to implement.

2) Co-ordinate with the schools, promote high levels of student attendance in school to organise experience-based learning, mostly experience-based learning activities belong to discovery and dedication mode.

3) Develop evaluation tables with appropriate evaluation criteria for each step of the process.

4) Encourage the application of experience-based learning to other subjects in the Bachelor of Biological Education Program.

5) Encourage students to promote their advantage of information technology and self-efficacy in experience-based learning activities. 


\section{Conclusions}

Today, experience-based learning is developed in many countries and is widely used in the education system, including professional education. Theoretical and practical studies allow us to study experience-based learning and explore how it works in instructing our students to conduct experience-based learning activities in high schools. From Kolb's experiential learning cycle, the process of guiding students to conduct experience-based learning activities in schools according to five activities was introduced. Implementing this process in two student courses in the academic year 2018-2019 and 2019-2020 in Faculty of Biology, Thai Nguyen University of Education. One hundred and nine students participated in the courses and 55 experience-based learning activities plans have been designed and organised. The results survey by the Linkert scale on awareness, skills, attitudes, and behaviours of the participating students in the courses showed the usefulness and feasibility of guiding students to approach the perform educational and teaching activities in high schools. The tutorial process will continue to be improved and implemented in subsequent courses. Since then, the research results have contributed to the improvement of the efficiency of experience-based learning activities in schools, and to the renovation of higher education to meet the renovation of general education in Vietnam.

Funding: This research received no external funding.

Conflicts of Interest: The authors declare no conflict of interest in the design of the study; in the collection, analysis, or interpretation of data; in the writing of the manuscript, or in the decision to publish the results.

\section{References}

Abdulwahed, M., \& Nagy, Z. K. (2013). Applying Kolb's experiential learning cycle for laboratory education. Journal of Engineering Education, 98(3), 283-294. https://doi.org/10.1002/j.2168-9830.2009.tb01025.x

Aissaoui, Q. E., Alami, Y. E., Oughdir, L., \& Allioui, Y. E. (2018). A fuzzy classification approach for learning style prediction based on web mining techniques in elearning environments. Education and Information Technologies, 24, 1943-1959. https://doi.org/10.1007/s10639-018-9820-5

Ahmed, M. H. (2018). Reflection for the undergraduate on writing in the portfolio: where are we now and where are we going? Journal Adv Med Educ Prof., 6(3), 97-101. PMID: 30013993

Akhigbe, T. (2018). Cognitive-behaviorism and experientialism in emergency medicine training: from theory to practice in a teaching hospital. International Journal of Medical Reviews, 5(3), 87-89. https:// doi.org/10.29252/IJMR-050301

American Association of Colleges of Teacher Education [AACTE]. (2018). A pivot toward clinical practice, its lexicon, and the renewal of educator preparation: A report of the AACTE Clinical Practice Commission. Washington, DC.

Amolloh, O. P., Lilian, G. K., \& Wanjiru, K. G. (2018). Experiential Learning, Conditional Knowledge and Professional Development at University of Nairobi, Kenya Focusing on Preparedness for Teaching Practice. International Education Studies, 11(7), 125-135. https://doi.org/10.5539/ies.v11n7p125

Andrews, A., Brown, B., \& Mesher, L. (2018). Engaging students with assessment and feedback: improving assessment for learning with students as partners. 
Practitioner Research in Higher Education Special Assessment Issue, University of Cumbria, 11(1), 32-46.

Andresen, L., Boud, D., \& Cohen, R (1995). Experience-Based Learning. In G. Foley (Ed.). Understanding Adult Education and Training (pp. 207-219). Sydney: Allen \& Unwin.

Angela, B. R., Bruce, W. B., Kevin, M. C., Mandar M. D., \& Kurtis G. P. (2011). Diverse Models for Incorporating Service Projects into Engineering Capstone Design Courses. International Journal of Engineering Education, 27(6), 1206-1220.

Awidi, I. T., \& Paynter, M. (2019). The impact of a flipped classroom approach on student learning experience. Computers \& Education, 128, 269-283. https:// doi.org/10.1016/j.compedu.2018.09.013

Bethell, S., \& Morgan, K. (2011). Problem-based and Experiential Learning: Engaging Students in an Undergraduate Physical Education Module. Journal of Hospitality, Leisure, Sport and Tourism Education, 10(1), 128-134. https://doi.org/10.3794/ johlste.101.365

Bhati, A., \& Song, I. (2019). New Methods for Collaborative Experiential Learning to Provide Personalised Formative Assessment. International Journal of Emerging Technologies in Learning (iJET), 14(7), 179-195. https://doi.org/10.3991/ ijet.v14i07.9173

Boud, D., Cohen, R., \& Walker, D. (eds) (1993). Using Experience for Learning (p. 189). Buckingham, England; Bristol, USA: Society for Research into Higher Education and Open University Press. Retrieved from https://catalogue.nla.gov.au/Record/1617372

Cao, C. G., Tran, T. G., \& Phan, T. T. H. (2017). Organizing the Experiential Learning Activities in Teaching Science for General Education in Vietnam. World Journal of Chemical Education 5(5), 180-184. https://doi.org/10.12691/wjce-5-5-7.

Chapman, S., McPhee, P., \& Proudman, B. (1984). What is Experiential Education? In K. Warren (Ed.), The Theory of Experiential Education (pp. 235-248). Dubuque: Kendall/Hunt Publishing Company.

Gomez, C., \& Nasir, S. (2019). Problem Based Learning: Generating a 3D Educational Brain Model to Engage Undergraduate Engineering Honors Students. Proceedings of the International Mechanical Engineering Congress and Exposition, Engineering Education (Vol. 5). https://doi.org/10.1115/imece2018-87197

Gorski, P. C. (2009). What we're teaching teachers: An analysis of multicultural teacher education coursework syllabi. Teaching and Teacher Education, 25, 309-318. https://doi.org/10.1016/j.tate.2008.07.008

Harfitt, G. (2019). Community-Based Experiential Learning in Teacher Education. Oxford Research Encyclopedia of Education. https://doi.org/10.1093/acrefore/9780190264093.013.986

Jamieson, S. (2004). Likert scales: how to (ab) use them. Medical Education, 38(12), 12171218. https://doi.org/10.1111/j.1365-2929.2004.02012.x

Kumar, P., \& Kumari, K. (2019). Experiential Learning, A story by Padhkar Kumar and Karkar Kumari. Delhi, India: Central Board of Secondary Education.

Kolb, A. Y., \& Kolb, D. A. (2005). Learning styles and learning spaces: Enhancing experiential learning in higher education. Academy of Management Learning $\mathcal{E}$ Education, 4(2), 193-212. Retrieved from https:// people.ok.ubc.ca/cstother/Learning\%20Styles\%20\&\%20Learning\%20Sp aces.pdf

Kolb, A. Y., \& Kolb D. A. (2017). Experiential Learning theory as a guide for experiential educators in Higher Education, A Journal for Engaged Educators, 1(1), 7-44. Retrieved from https://nsuworks.nova.edu/elthe/vol1/iss1/7 
Louise, K. (1994). Action Learning: Executive Development of Choice for the 1990s. Journal of Management Development, 13(8), 50-56. https://doi.org/10.1108/ 02621719410071982

McLeo, S. (2017). Kolb's Learning Styles and Experiential Learning Cycle. Simply Psychology. Retrieved from https://www.simplypsychology.org/learningkolb.html

Miettinen, R. (2000). The concept of experiential learning and John Dewey's theory of reflective thought and action. International Journal of Lifelong Education, 19(1), 5472. https://doi.org/10.1080/026013700293458

Nieto, S. (2013). Language, literacy, and culture: Aha! Moments in personal and sociopolitical understanding. Journal of Language and Literacy Education, 9(1), 8-20. Retrieved from http://jolle.coe.uga.edu/wpcontent/uploads/2013/05/Language-Literacy-Culture.pdf

Patil, M., \& Meena, M. (2018). Effect of Practicing Experiential Learning (Like Online Learning - ICT) in Engineering Education. Journal of Engineering Education Transformations, 31(3), 95-101. Retrieved from https://www.researchgate.net/publication/ 322569795_Effect_of_Practicing_Experiential_Learning_Like_Online_LearningICT_in_Engineering_Education

Razali, F., Manaf, U. K. A. M., \& Ayub, A. F. M. (2020). STEM Education in Malaysia towards Developing a Human Capital through Motivating Science Subject. International Journal of Learning, Teaching and Educational Research, 19(5), 411-422. https:// doi.org/10.26803/ijlter.19.5.25

Richard, B. E., Cowen, S. S., \& Kolb D. A. (1995). Innovation in Professional Education: Steps on a Journey from Teaching to Learning (Vol. 9, Iss. 2). Jossey-Bass Publishers. https:// doi.org/10.5465/ame.1995.9506273286

Setiyani, R., Harnanik, Lianighsih, S., \& Susilowati, N. (2020). Using the Blended Learning to Enhance Students' Engagement and Learning Experience in Taxation. KnE Social Sciences / International Conference on Economics, Business and Economic Education, 397-408. https://doi.org/10.18502/kss.v4i6.6615

Simosko, S. (1988). Assessing Learning: A CAEL Handbook for Faculty. Chicago: Council for Adult \& Experiential Learning.

Stefano, G. D., Ruvolo, G., \& Mauro, V. L. (2019). Developing professional identity through group experiential learning: A Group-Analytic experiential training approach for use with postgraduate clinical psychology students. Journal of Psychodynamic Practice, 25 , 133-143. https:// doi.org/10.1080/14753634.2019.1603809

Stephanie, A., Lockwood, Hill, S., \& Randell, S. (2020). Engaging Students in Experiential Learning: Texas Integrated Diving and Ecological Studies (TIDES) Laboratory. Advances in Biology Laboratory Education, 41. https://doi.org/10.37590/able.v41. extabs73

Supardi, S., \& Hasanah, E. (2020). Junior High School Students' Experiences of High Technology Based Learning in Indonesia. International Journal of Learning, Teaching and Educational Research, 19(5), 153-166. https://doi.org/10.26803/ijlter.19.5.9

Tinkler, A., Tinkler, B., Reyes, C., \& Elkin, S. (2018). Critical Service-Learning: Learning Through Experience to Advance Teacher Education. Journal of Experiential Education, 42(1), 65-78. https://doi.org/10.1177/1053825918820662

Tiessen, R., Grantham, K., \& Cameron, J. (2018). The Relationship Between Experiential Learning and Career Outcomes for Alumni of International Development Studies Programs in Canada. Canadian Journal of Higher Education, 48(3), 23-42. 
Retrieved

from

https://journals.sfu.ca/cjhe/index.php/cjhe/article/view/188187/186273

Viet Nam Ministry of Education and Training. (2018). General education curriculum 2018. (In Vietnamese). Retrieved from https://moet.gov.vn/tintuc/Pages/tin-hoatdong-cua-bo.aspx?ItemID $=5755$

Wallace, D. (2018) Parts of the Whole: Theories of Pedagogy and Kolb's Learning Cycle. Numeracy, 12(1). https:// doi.org/10.5038/1936-4660.12.1.17

Widiastuti, I., \& Budiyanto, C. W. (2018). Applying an Experiential Learning Cycle with the Aid of Finite Element Analysis in Engineering Education. Journal of Turkish science education, 15(Special Issue), 97-103. https://doi.org/10.12973/tused.10261a

Zhang, J., Xie, H., Schmidt, K., Xia, B., Li, H., \& Skitmore, M. (2019). Integrated Experiential Learning-Based Framework to Facilitate Project Planning in Civil Engineering and Construction Management Courses. Journal of Professional Issues in Engineering Education and Practice, 145(4). https://doi.org/10.1061/(ASCE)EI.1943-5541.0000421 